\title{
Principles of Indirect Tax Harmonization in the EU
}

\author{
Jaroslav Korečko, Alžbeta Suhányiová, Ladislav Suhányi \\ University of Prešov, Prešov, Slovakia
}

\begin{abstract}
Since the beginning of $60 \mathrm{~s}$ of the 20th century the European Community has been voicing its concerns about the need for tax harmonization. First attitudes towards tax harmonization were very ambitious. The aim was not only to reach structural harmonization in the Member States, but also harmonization of tax base and tax rates. The article explores the nature and conditions of the harmonization process while addressing its legislative modifications. The article analyses and compares the most important indirect taxes (value added tax, excise duties) in the Member States of the EU. Despite decades of efforts to harmonize taxes countries continuously apply national taxes. Heads of the Union argue that this approach can lead to disintegration in the future.
\end{abstract}

Keywords: harmonization, competition, VAT (value added tax), excise duty

\section{Introduction}

Following the partial failure to implement harmonization measures, the notion of tax harmonization has begun to be closely linked with the single internal market and its smooth functioning. Still, there are clashing opinions whether it is better to preserve tax competition (i.e. a situation where there are different tax systems and different tax rates via which states seek to attract investors), or seek tax harmonization from two points of view-within the European Communities and the individual Member States.

According to Babčák (2015), the background of the harmonization process in the EU is characterized by the process of gradual reform steps, which required a constant search for compromise solutions. The indirect taxation is - clearly and without any calling into question - "soaked" by the legal rules of the EU in the most significant way.

The harmonization of indirect taxes has resulted in consequences especially in the national legislation of VAT. When comparing the results of the harmonization between VAT and excise duties, we believe that the VAT harmonization is far more complex than in case of excise duties. However, the harmonization of indirect taxes is accompanied by a number of practical problems. For example, in some instances the rules implemented in the EU directive are interpreted in different ways by Member States. Several states have temporary exceptions from the common rules (and not always are these exemptions and reductions justified and reasonable). Problematic seems also the practical implementation of taxation by the VAT by applying the principle of the country of origin, etc.

Acknowledgement: The article was written under the project VEGA 1/0596/14 and the project KEGA 058PU-4/2015.

Jaroslav Korečko, assistant professor, University of Prešov, Prešov, Slovakia.

Alžbeta Suhányiová, associate professor, University of Prešov, Prešov, Slovakia.

Ladislav Suhányi, associate professor, University of Prešov, Prešov, Slovakia.

Correspondence concerning this article should be addressed to Jaroslav Korečko, Konštantínova 16, Prešov 08001, Slovakia. 


\section{Materials, Methods, and Literature Overview}

Tax harmonization is a process of tax systems convergence on the basis of common rules. The situation where some countries use common tax provisions along with tax provisions of national character is called partial tax harmonization. The tax theory defines total harmonization as a result of structural harmonization and harmonization of tax rates.

Tax harmonization can be understood as a process and as a result at the same time. The notion of tax harmonization within the European Communities is defined as the introduction of a single market and its smooth functioning (Nerudová, 2005). If tax harmonization is perceived as a tool through which a single market could be achieved, we can divide it into positive and negative. Harmonization is a positive process of convergence through the implementation of regulations, directives and other legal instruments. If all Member States are bound by same rules, the result is positive harmonization. The best way to achieve a genuine single market is though positive harmonization.

Results of activities carried out by the European Court of Justice (ECJ) are perceived as negative harmonization. If national tax systems feature measures based on the tax laws of the ECJ instead of being based on regulations or directives, we are talking about negative harmonization. Since it does not provide Member States with the same rules, negative harmonization cannot be perceived as harmonization in the true sense (Solík, 2007).

Given the recent developments in the field of tax harmonization, harmonization can still be divided into direct and indirect harmonization. Direct harmonization could be perceived as a classical harmonization process which seeks to harmonize tax provisions directly - that is through tax directives. Indirect harmonization strives for harmonization of certain tax provisions through other areas of law-for example business law.

\section{Tax Harmonization and Competition}

The first factor speaking against tax harmonization in the European Community is a need to maintain maximum fiscal autonomy. In the context of the monetary union the role of national banks is limited because their powers were partly taken over by the European Central Bank. Member countries therefore can intervene into their own economy only using fiscal instruments (mainly taxes and the level of government spending). Therefore the use of fiscal instruments should be autonomous so states would have an opportunity to cope with economic shocks by themselves. Another even more important reason for the negative attitude towards tax harmonization is the fact that tax rates correspond to the preferences and particulars of the Member States.

Tax competition in itself can lead to the so-called spontaneous harmonization effect. It is a spontaneous convergence of rates and therefore it is not necessary to harmonize taxes artificially. This effect may occur, for example, between the two neighbouring countries in case of value added tax. Residents of one member country can buy goods in a neighbouring Member State which has a lower rate of value added tax. Therefore such a neighbouring Member State is a cheaper place to buy goods. Such a situation will cause the so-called spontaneous harmonization effect-spontaneous convergence of tax rates.

Negative aspects of harmonization can be summarized as follows: harmonization leading to higher tax rates - without the competitive pressure the government sets a higher tax rate, i.e. harmonization does not create pressure on the budget spending; harmonizing causes slower economic growth - higher tax rates reduce overall productivity and deters foreign investments; does not prevent excessive expansion in the public sector; interferes with national sovereignty of Member States; may pose a serious risk to the budget revenue of 
countries with higher tax rates for which tax harmonization is an essential part of state budget revenues; brings about the loss of fiscal autonomy.

Tax competition may lead to the following issues: the tax burden on the immobile factors is increasing, especially labour. Conversely, the tax burden on highly mobile factors, especially capital, is decreasing. It leads to the inappropriate structure of government spending since the government provides a variety of incentives, subsidies, and support to attract investments.

\section{Cluster Analysis}

There has been used the cluster analysis to find the similarity between Member States. The objective was to suggest the next steps in the process of indirect tax harmonization.

Basic methods of clustering we used were:

Hierarchical methods are based on sequentially joining of clusters, their number decreases continuously until finally all clusters are combined into one. The output is graphically displayed as a tree diagram (dendrogram) (Farley, Raftery, Murphy, \& Luca Scrucca, 2012).

Ward's method involves an agglomerative clustering algorithm. It looks for groups of leaves that it forms into branches, branches into limbs and eventually into the trunk. Ward's method starts out with $n$ clusters of size 1 and continues until all the observations are included into one cluster (Pennsylvania State University, 2004).

Ward's method uses the Euclidean distance defined by formula:

$$
d_{i j}=\sqrt{\sum_{k=1}^{K}\left(x_{i k}-x_{j k}\right)^{2}}
$$

where $x_{i k}$ is the value of " $k$ " variable for $i$-th object and $x_{j k}$ is the value of " $k$ " variable for $j$-th object. Calculated distance determines the rule of linking statistical units in clusters.

There were " $p$ " objects in analyzed group, namely 28 countries in which we pursued " $k$ " quantitative characters (two variables - VAT and Excise duties and consumption taxes).

\section{Results}

According to Directive 67/227/EEC, the introduction of VAT is important for the following reasons: the creation of a common market with healthy competition which acts as a national market; exclusion of factors which may distort conditions of competition at national level; abolish tax on imports and tax refunds on exports in trade between Member States; VAT reaches the greatest simplicity and neutrality.

\section{Value Added Tax}

With effect from 1993 Directive 92/77/EEC has introduced the minimum limit of VAT. The standard minimum VAT rate was $15 \%$ and the reduced VAT rate was $5 \%$. It also stipulated that Member States may apply only two reduced rates. In 2007, Directive 2007/75/EC has been adopted which allowed Poland to use the exemption with the entitlement to deduct taxes on deliveries of books and magazines by the end of 2010. Also, by the end of 2010 it allowed the use of reduced VAT rates no lower than $7 \%$ for the provision of selected services. Directive 2010/88/EU has extended the period to 31st December 2015 stating that the basic VAT rate shall not be lower than $15 \%$. 
Table 1

Development of the Standard VAT Rate in EU Member States

\begin{tabular}{|c|c|c|c|c|c|c|c|}
\hline Country & 2009 & 2010 & 2011 & 2012 & 2013 & 2014 & 2015 \\
\hline Belgium & 21 & 21 & 21 & 21 & 21 & 21 & 21 \\
\hline Bulgaria & 20 & 20 & 20 & 20 & 20 & 20 & 20 \\
\hline Cyprus & 15 & 15 & 15 & 17 & 18 & 19 & 19 \\
\hline Czech Republic & 19 & 20 & 20 & 20 & 21 & 21 & 21 \\
\hline Denmark & 25 & 25 & 25 & 25 & 25 & 25 & 25 \\
\hline Estonia & 20 & 20 & 20 & 20 & 20 & 20 & 20 \\
\hline Finland & 22 & 23 & 23 & 23 & 24 & 24 & 24 \\
\hline France & 19.6 & 19.6 & 19.6 & 19.6 & 19.6 & 20 & 20 \\
\hline Greece & 19 & 23 & 23 & 23 & 23 & 23 & 23 \\
\hline Netherlands & 19 & 19 & 19 & 19 & 21 & 21 & 21 \\
\hline Croatia & 22 & 23 & 23 & 25 & 25 & 25 & 25 \\
\hline Ireland & 21.5 & 21 & 21 & 23 & 23 & 23 & 23 \\
\hline Lithuania & 19 & 21 & 21 & 21 & 21 & 21 & 21 \\
\hline Latvia & 21 & 21 & 22 & 22 & 21 & 21 & 21 \\
\hline Luxembourg & 15 & 15 & 15 & 15 & 15 & 15 & 17 \\
\hline Hungary & 25 & 25 & 25 & 27 & 27 & 27 & 27 \\
\hline Malta & 18 & 18 & 18 & 18 & 18 & 18 & 18 \\
\hline Germany & 19 & 19 & 19 & 19 & 19 & 19 & 19 \\
\hline Poland & 22 & 22 & 23 & 23 & 23 & 23 & 23 \\
\hline Portugal & 20 & 21 & 23 & 23 & 23 & 23 & 23 \\
\hline Austria & 20 & 20 & 20 & 20 & 20 & 20 & 20 \\
\hline Romania & 19 & 24 & 24 & 24 & 24 & 24 & 24 \\
\hline Slovakia & 19 & 19 & 20 & 20 & 20 & 20 & 20 \\
\hline Slovenia & 20 & 20 & 20 & 20 & 22 & 22 & 22 \\
\hline Spain & 16 & 18 & 18 & 18 & 21 & 21 & 21 \\
\hline Sweden & 25 & 25 & 25 & 25 & 25 & 25 & 25 \\
\hline Italy & 20 & 20 & 20 & 21 & 21 & 22 & 22 \\
\hline United Kingdom & 15 & 17.5 & 20 & 20 & 20 & 20 & 20 \\
\hline EU-28 & 19.9 & 20.5 & 20.8 & 21.1 & 21.5 & 21.5 & 21.6 \\
\hline
\end{tabular}

Source: processed according to the taxation trends in the European Union.

According to the table above it is clear that all EU Member States respect a minimum level of basic VAT rate that is in accordance with Directive 92/77/EEC set at 15\%. Currently, the highest VAT rate $25 \%$ is present in Denmark, Croatia, and Sweden. Luxembourg as the only state in 2014 had opted for the minimum VAT rate $15 \%$, in 2015 the rate increased to $17 \%$. 
Table 2

Development of Reduced VAT Rates in EU Member States

\begin{tabular}{|c|c|c|c|c|c|c|c|}
\hline Country & 2009 & 2010 & 2011 & 2012 & 2013 & 2014 & 2015 \\
\hline Belgium & $6 / 12$ & $6 / 12$ & $6 / 12$ & $6 / 12$ & $6 / 12$ & $6 / 12$ & $6 / 12$ \\
\hline Bulgaria & 7 & 7 & 9 & 9 & 9 & 9 & 9 \\
\hline Cyprus & $5 / 8$ & $5 / 8$ & $5 / 8$ & $5 / 8$ & $5 / 8$ & $5 / 9$ & $5 / 9$ \\
\hline Czech Republic & 9 & 10 & 10 & 14 & 15 & 15 & $10 / 15$ \\
\hline Denmark & - & - & - & - & - & - & - \\
\hline Estonia & 9 & 9 & 9 & 9 & 9 & 9 & 9 \\
\hline Finland & $8 / 17$ & $9 / 13$ & $9 / 13$ & $9 / 13$ & $10 / 14$ & $10 / 14$ & $10 / 14$ \\
\hline France & $5.5 / 2.1$ & $5.5 / 2.1$ & $5.5 / 2.1$ & $5.5 / 7 / 2.1$ & $5.5 / 7 / 2.1$ & $5.5 / 10 / 2.1$ & $5.5 / 10 / 2.1$ \\
\hline Greece & $9 / 4.5$ & $5.5 / 11$ & $6.5 / 13$ & $6.5 / 13$ & $6.5 / 13$ & $6.5 / 13$ & $6.5 / 13$ \\
\hline Netherlands & 6 & 6 & 6 & 6 & 6 & 6 & 6 \\
\hline Croatia & $10 / 0$ & $10 / 0$ & $10 / 0$ & $10 / 0$ & $5 / 10$ & $5 / 13$ & $5 / 13$ \\
\hline Ireland & $13.5 / 4.8$ & $13.5 / 4.8$ & $13.5 / 9 / 4.8$ & $13.5 / 9 / 4.8$ & $13.5 / 9 / 4.8$ & $13.5 / 9 / 4.8$ & $13.5 / 9 / 4.8$ \\
\hline Lithuania & $5 / 9$ & $5 / 9$ & $5 / 9$ & $5 / 9$ & $5 / 9$ & $5 / 9$ & $5 / 9$ \\
\hline Latvia & 10 & 10 & 12 & 12 & 12 & 12 & 12 \\
\hline Luxembourg & $6 / 12 / 3$ & $6 / 12 / 3$ & $6 / 12 / 3$ & $6 / 12 / 3$ & $6 / 12 / 3$ & $6 / 12 / 3$ & $8 / 14 / 3$ \\
\hline Hungary & $5 / 18$ & $5 / 18$ & $5 / 18$ & $5 / 18$ & $5 / 18$ & $5 / 18$ & $5 / 18$ \\
\hline Malta & 5 & 5 & $5 / 7$ & $5 / 7$ & $5 / 7$ & $5 / 7$ & $5 / 7$ \\
\hline Germany & 7 & 7 & 7 & 7 & 7 & 7 & 7 \\
\hline Poland & $7 / 3$ & $7 / 3$ & $5 / 8$ & $5 / 8$ & $5 / 8$ & $5 / 8$ & $5 / 8$ \\
\hline Portugal & $5 / 12$ & $6 / 13$ & $6 / 13$ & $6 / 13$ & $6 / 13$ & $6 / 13$ & $6 / 13$ \\
\hline Austria & 10 & 10 & 10 & 10 & 10 & 10 & 10 \\
\hline Romania & $5 / 9$ & $5 / 9$ & $5 / 9$ & $5 / 9$ & $5 / 9$ & $5 / 9$ & $5 / 9$ \\
\hline Slovakia & 10 & $6 / 10$ & 10 & 10 & 10 & 10 & 10 \\
\hline Slovenia & 8.5 & 8.5 & 8,5 & 8.5 & 9.5 & 9.5 & 9.5 \\
\hline Spain & $7 / 4$ & $8 / 4$ & $8 / 4$ & $8 / 4$ & $10 / 4$ & $10 / 4$ & $10 / 4$ \\
\hline Sweden & $6 / 12$ & $6 / 12$ & $6 / 12$ & $6 / 12$ & $6 / 12$ & $6 / 12$ & $6 / 12$ \\
\hline Italy & $10 / 4$ & $10 / 4$ & $10 / 4$ & $10 / 4$ & $10 / 4$ & $10 / 4$ & $10 / 4$ \\
\hline United Kingdom & 5 & 5 & 5 & 5 & 5 & 5 & 5 \\
\hline
\end{tabular}

Source: processed according to the taxation trends in the European Union.

According to Table 2 it is clear that some EU Member States do not respect the obligation to apply only two reduced rates of VAT. This obligation is not being respected by France, Ireland, and Luxembourg. Moreover, the minimum threshold of a reduced rate of VAT in accordance with Directive 92/77/EEC - 5\% is also not being respected. France still applies a reduced VAT rate of $2.1 \%$, Ireland applies a reduced VAT rate of $4.8 \%$, and Luxembourg applies a reduced VAT rate of 3\%. By 2009, Greece applied a reduced VAT rate of $4.5 \%$, and up to 2012 Croatia applied a reduced VAT rate of $0 \%$. 


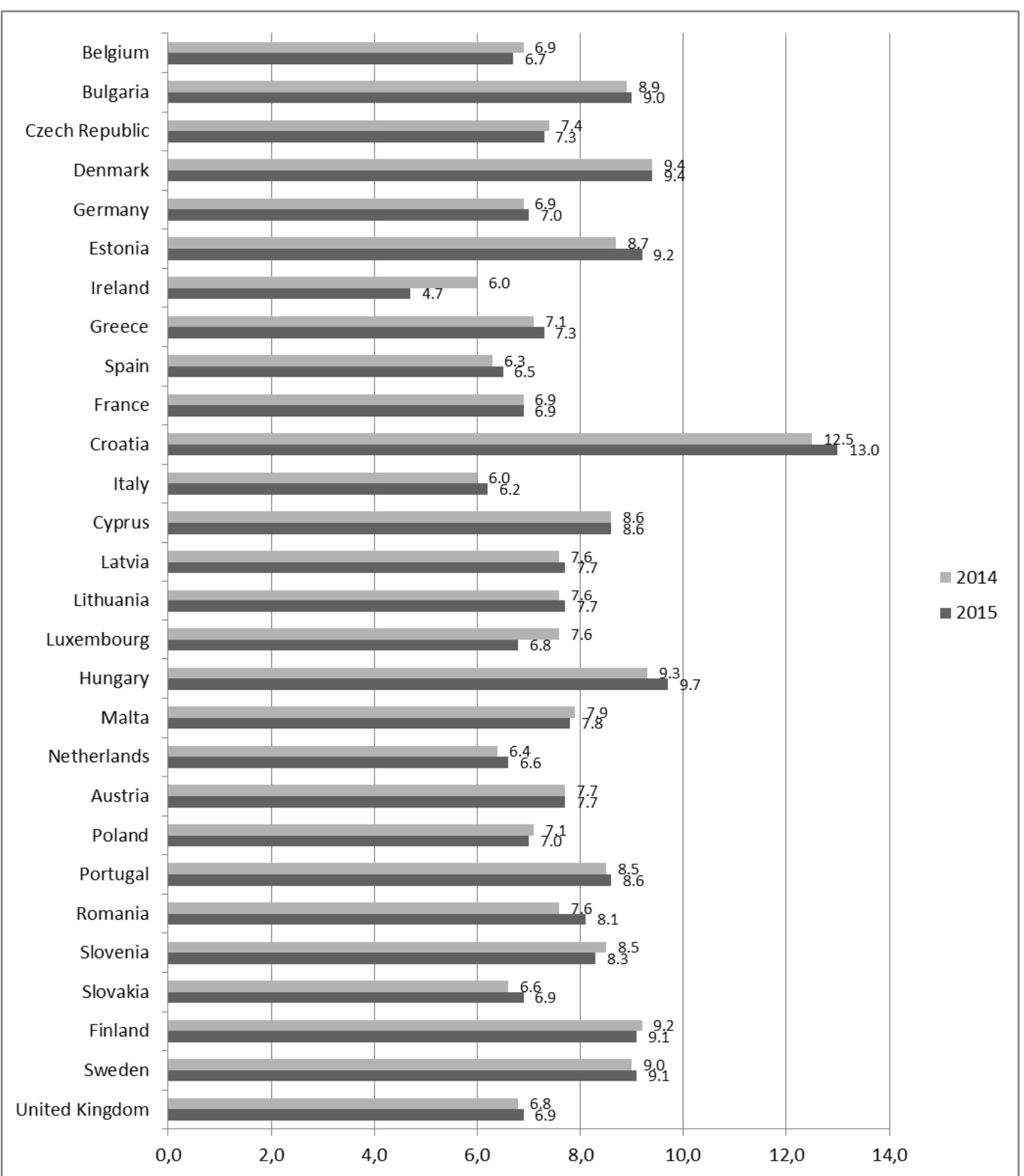

Figure 1. VAT revenues in EU Member States between 2014 and 2015 (in \% of GDP). Source: processed using Eurostat.

Croatia generates the highest revenues from VAT at the level of $12.5 \%$ of GDP (Figure 1), which is 5.5\% more than the EU average which is equal to 7\% of GDP. The lowest VAT revenues are generated by Italy at the level of $6 \%$ of GDP. Slovakia generates revenue from VAT at the level of $6.6 \%$ of GDP. The European Union generates VAT revenue amounting to $975,901.6$ million EUR. The highest VAT revenues are made by Germany (203,081 mil. EUR). The lowest VAT revenues are generated by Malta, where VAT revenues amount to EUR 642.2 million EUR. 


\section{Excise Duties}

The ground-breaking date for the harmonization of excise duties was the day of the introduction of the single market on 1st January 1993. On this day entered into force Directive 92/12/EEC, which is essential for the harmonization of excise duties. This Directive outlines the products which are subject to excise duty like mineral oils, alcohol and alcoholic beverages, and tobacco. That Directive was in 2008 replaced by a new Directive 2008/118/EC on the general arrangements for excise duty.

Products affected by excise duties (EC 2016):

Alcohol/Alcoholic Drinks:

- Beer or mixtures of beer with non-alcoholic drinks;

- Wine;

- Other fermented drinks such as cider;

- Intermediate products such as sherry or port;

- Ethyl alcohol - except when it is used to manufacture other products not intended for human consumption (if used for heating or propulsion it may be classified as an energy product);

- Spirits.

Energy Products and Elektricity:

- Motor fuel;

- Fuel for heating.

Energy products used as raw materials or for the purposes of chemical reduction, or in electrolytic and metallurgical processes are out of the scope of the Directive, which means that the Member States may or may not decide to levy a tax on such use.

The main taxed products are:

- Mineral oils;

- Solid fuels: coal, coke, lignite;

- Natural gas;

- Electricity;

- Alcohols, if they are intended for use as heating fuel or motor fuel;

- Animal or vegetable oils, if they are intended for use as heating fuel or motor fuel.

Tobacco Products:

- Cigarettes;

- Cigars;

- Cigarillos;

- Smoking tobacco (such as fine cut rolling tobacco).

The EU legislation lays down the principles of taxation and sets the minimum rates to be applied.

Revenues from excise duties in selected EU countries are shown in the following Figure 2. 


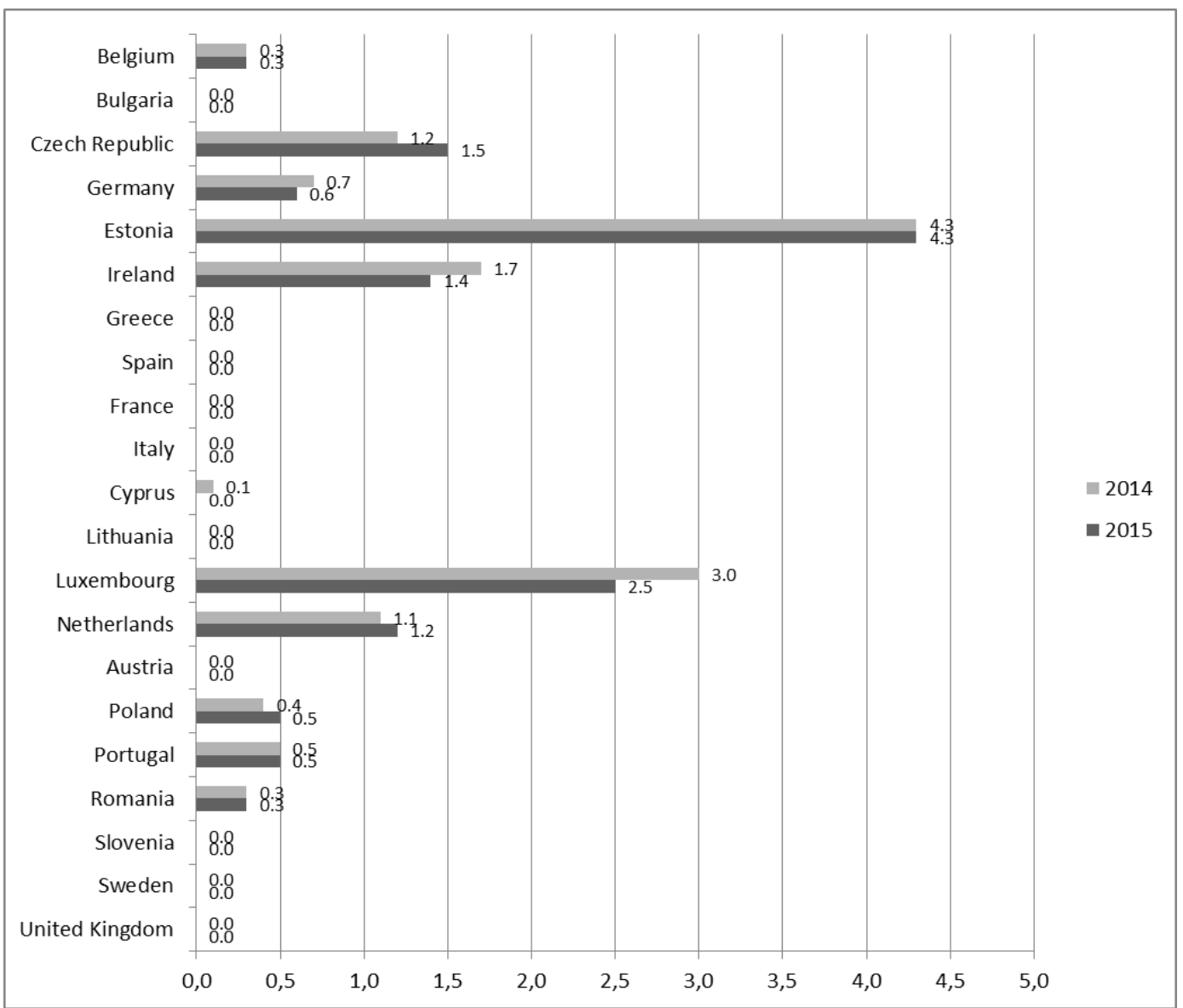

Figure 2. Excise duties revenues in EU Member States between 2014 and 2015 - only available data (in \% of GDP). Source: processed using Eurostat.

Directive 92/81/EEC from 1992 defines different types of mineral oils which are subject to excise duty. The subject of the Directive is mineral oil that is intended for the consumption, is further sold and/or used as fuel. Directive 2003/96/EC amends the taxation of energy products and electricity. This Directive expands the taxation of mineral oils and covers coal, natural gas, and electricity. Some Member States use other types of taxes of environmental nature, for example waste tax, tax on fertilizers, packaging tax, pollution tax and other.

Taxation of alcohol and alcoholic beverages is regulated by Directive 92/83/EEC. Directive divides the above products mentioned into beer, wine, intermediate products, and alcohol and alcoholic beverages. Excise duty on beer is covered by Directive 92/84/EEC. The Directive sets a minimum tax rate of $€ 0.748 / \mathrm{hL}$ of beer. Excise duty on wine is covered by Directive 92/84/EEC which distinguishes between still wine and sparkling wine. For both products there is a minimum tax rate of $€ 0 / \mathrm{Hl}$. The zero rate was introduced due to the reluctance of traditional wine producers (France, Spain, Italy) to adopt this tax. The minimum rate for intermediate products is set at $€ 45 / \mathrm{hL}$. Excise duty on alcohol and alcoholic beverages is subject to Directive 92/84/EEC. The Directive sets a minimum tax rate to $€ 550 / \mathrm{hL}$ of pure alcohol (EC, 2015). 
Directive 95/59/EC governs the taxation of tobacco products. Directive divides the above tobacco products into cigarettes, cigars and cigarillos, fine-cut tobacco for the rolling of cigarettes and other tobacco for smoking. Directive 2010/12/EU with effect from 1st January 2014 sets tax on cigarettes to $60 \%$ of their average retail selling price. This tax must not be less than $€ 90$ per 1,000 cigarettes. For cigars and cigarillos Directive sets a tax of 5\% of the retail selling price, including taxes, or $€ 12$ per 1,000 pieces or a kilogram. With regard to tobacco intended for smoking directive imposes a tax of $20 \%$ of the retail selling price, including taxes, or $€ 22$ per kilogram. Tax rates for fine-cut tobacco for rolling cigarettes have been since 1st January 2015 set at $46 \%$ of the retail selling price, including taxes, or €54 per kilogram. Entering into force on 1st January 2018 the tax rate will amount to $48 \%$ of the retail selling price, including taxes, or $€ 60$ per kilogram, these numbers will rise to $50 \%$ of the retail selling price, including taxes, or $€ 60$ per kilogram starting 1st January 2020.

\section{Cluster Analysis}

We identified four groups of countries with similar characteristics in the dendrogram (Figure 3). These groups are highlighted. The tree diagram includes two larger groups of countries and two smaller clusters.

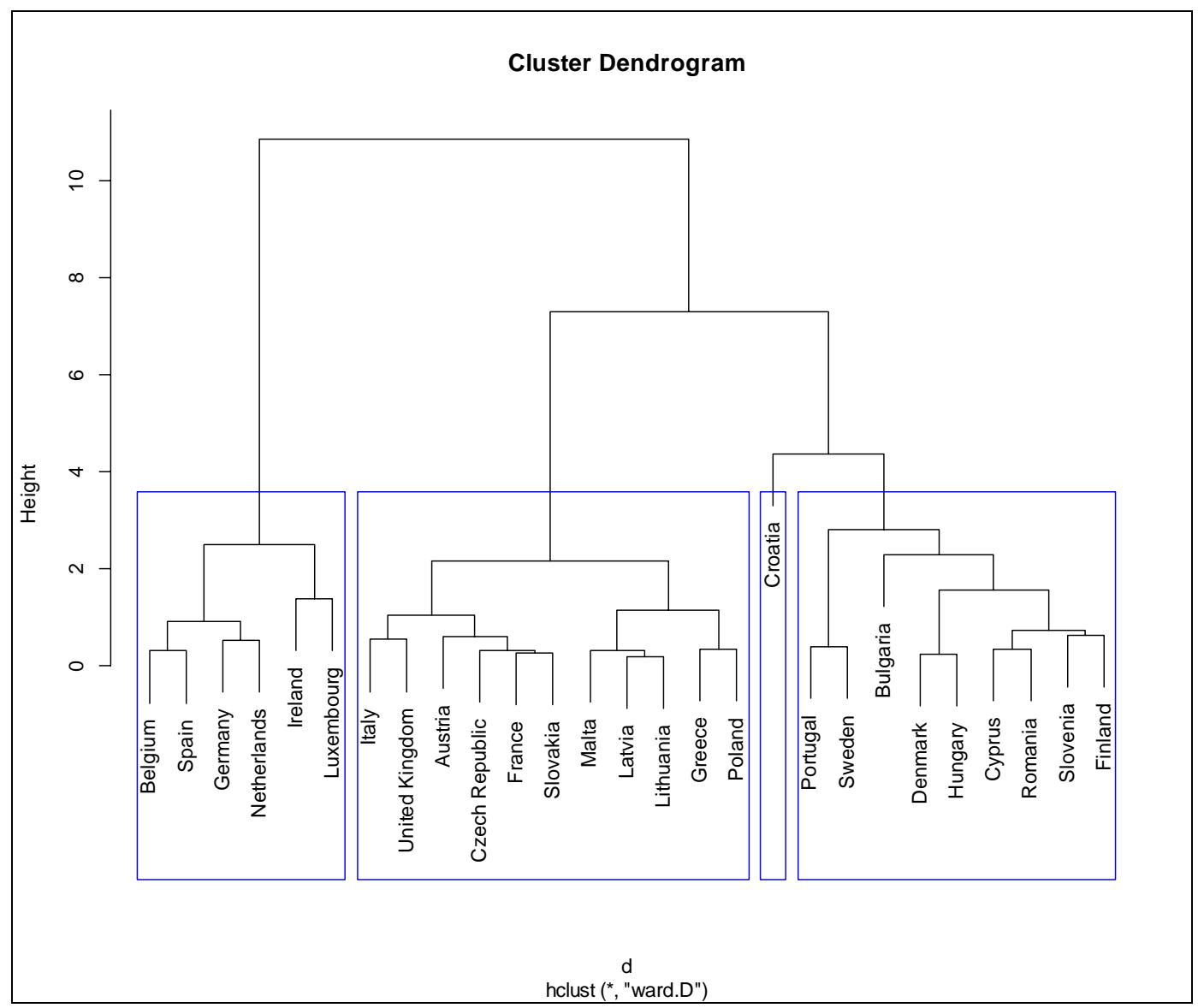

Figure 3. Cluster dendrogram. Source: processed using Eurostat.

So the next step in the harmonization process could be continuing first with further harmonization within the clusters, only then in the whole EU. 


\section{Conclusion}

Despite the fact that the tax harmonization had been the centre of attention already in the 60s of the 20th century, there are still ever-clashing opinions on whether it is better to preserve tax competition or opt for tax harmonization. EU Member States are aware that the harmonization of value added tax may lead to substantial alterations in tax structures and may have consequences in the budgetary, social, and political spheres. Given these circumstances, own national interests and awareness of the need for unanimous decisions on tax matters of all $28 \mathrm{EU}$ Member States, it is impossible to expect major changes in VAT policies. This concerns the principle of the transition from the country of destination to the country of origin. However, the principle assumed a single tax rate across the EU because otherwise a product offered on markets with different tax rates would be sold for different prices. It can be assumed that the current system of the country of destination will remain unchanged. It is a proven system and Member States are not inclined to align their tax rates.

\section{References}

Babčák, V. (2015). Europeanization of the Slovak Tax Lax (Reality and Vision). In: Iuset Administration 1/2015. Faculty of Law and Administration of the University of Rzeszów. pp. 4-46. ISSN 2300-4797. From http://gb.iusetadministratio.eu/-571.html

Eur-Lex. (2017). Directive 67/227/EEC. Retrieved March 11, 2017, from http://eur-lex.europa.eu/legal-content/EN/TXT/?uri=CELEX\%3A31967L0227

Eur-Lex. (2017). Directive 92/77/EEC. Retrieved March 18, 2017, from http://eur-lex.europa.eu/legal-content/ $\mathrm{EN} / \mathrm{TXT} /$ ?uri=celex\%3A31992L0077

Eur-Lex. (2017). Directive 2007/75/EC. Retrieved March 18, 2017, from http://eur-lex.europa.eu/legal-content/ EN/ALL/?uri=CELEX:32007L0075

Eur-Lex. (2017). Directive 2010/88/EU. Retrieved March 25, 2017, from http://eur-lex.europa.eu/eli/dir/2010/88/oj

Eur-Lex. (2017). Directive 92/12/EEC. Retrieved March 25, 2017, from http://eur-lex.europa.eu/LexUriServ/ LexUriServ.do?uri=CELEX:31992L0012:en:HTML

Eur-Lex. (2017). Directive 2008/118/EC. Retrieved March, 2017, from http://eur-lex.europa.eu/LexUriServ/ LexUriServ.do?uri=OJ:L:2009:009:0012:0030:EN:PDF

Eur-Lex. (2017). Directive 92/81/EEC. Retrieved March 26, 2017, from http://eur-lex.europa.eu/legal-content/ en/ALL/?uri=CELEX:31992L0081

Eur-Lex. Directive 2010/12/EU. Retrieved $\quad$ March $\quad 26, \quad$ 2017, from http://eur-lex.europa.eu/LexUriServ/LexUriServ.do?uri=OJ:L:2010:050:0001:0007:EN:PDF

European Commission. (2015). Taxation trends in the European Union. Retrieved March 10, 2017, from http://ec.europa.eu/eurostat/documents/3217494/7092073/KS-DU-15-001-EN-N.pdf/68116dc2-75bc-4f25-b8a3-ae863ff8dec 5

Eurostat. (2016). Government finance and EDP statistics. Retrieved February 25, 2017, from http://ec.europa.eu/eurostat/web /government-finance-statistics/data/database

Fraley, C., Raftery, A. E., Murphy, T. B., \& Luca Scrucca, L. (2012). Mclust version 4 for R: Normal mixture modeling for model-based clustering, classification, and density estimation. Technical report No. 597. Department of Statistics, University of Washington.

Nerudová, D. (2005). HarmonizacedaňovýchsystémůzemiEvropskéunie [Harmonization of the tax systems of the European Union]. Praha: ASPI. ISBN 80-7357-142-0.

Pensylvania State University. (2004). Cluster analysis. Retrieved February 26, 2017, from http://sites.stat.psu.edu/ ajw13/stat505/fa06/19_cluster/09_cluster_wards.html

Solík, J. (2007). Súčasnýstav a tendencievývojaharmonizáciedaní v Európskejúnii [The current situation and tendencies of the tax harmonization in the European Union]. Bratislava, Nadácia F. A. Hayeka. ISBN 978-80-969833-0-8. 